\title{
The Power of Law vs. the Power of Arms: The Turkish Judiciary's Test with the Coup
}

\author{
HÜSEYIN AYDIN*
}

\begin{abstract}
Thousands of judges and prosecutors in Turkey risked their lives to inquire into the activities of an armed group and defended the law against them. The Turkish judiciary has been determined to protect the democratic constitutional state since the night of the coup attempt on July 15, 2016. Even during the early hours of the coup attempt, when nobody yet knew whether it would be successful, the Turkish judiciary showed the courage to initiate investigations against the coup-plotters. Since then, the judiciary has spent utmost effort to ensure the conduct and conclusion of the proceedings in a fair manner. This paper will shed light on the judicial process during the post-coup attempt period.
\end{abstract}

\section{The Road to the Coup}

$\mathrm{T}$ he Fetullah Terror Organization (FETÖ), ${ }^{1}$ which used to be seen as a civilian religious formation for many years before being recognized as a terrorist organization by the judicial verdict, had taken an overt position in the Turkish political struggle in the period leading up to the coup attempt. Having openly supported the opposition bloc in the June 7, 2015 general elections, the organization hoped that the pressure on it would diminish with the election results. However, the political picture which emerged with the AK Party's (Justice and Development Party) landslide victory in the fol- lowing early elections on November 1, 2015 produced a shock effect on the Gülenist organization. The fact that the AK Party would govern the country for another four years was a total nightmare for the Gülenists. The strengthening of the political will which had already been conducting the struggle against the organization -particularly for the preceding two years- signaled that a stronger push would continue for another four years. That could lead to an irreversible weakening of the organization and eventually its elimination.

With a renewed and far-reaching vigor, the AK Party, led by President Recep Tayyip Erdoğan, seemed deter-
* Lawyer, Ankara, Turkey

Insight Turkey Vol. 21 / No. 4 / 2019, pp. 41-52 


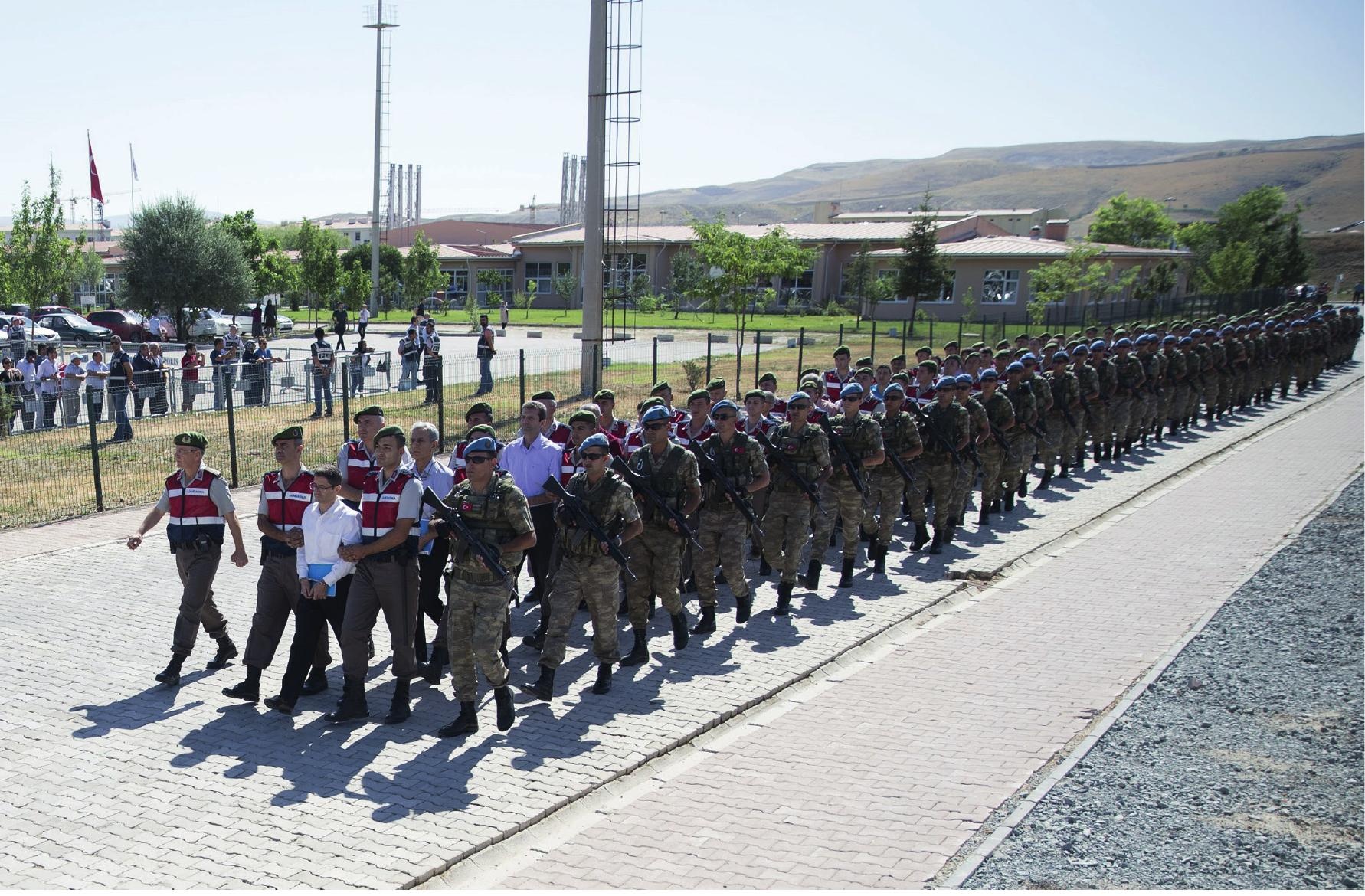

Defendants

Kemal Batmaz

(first row C), Akın

Öztürk (second

row $2^{\text {nd }} \mathrm{L}$ ) and

other defendants

arrive for their

trial accompanied

with gendarmerie

commandos of

Sincan Penal

Institution at

Ankara $4^{\text {th }}$ Heavy

Penal Court in

Ankara, Turkey on

August 1, 2017.

MUSTAFA KAMACI/

AA Photo mined to strike one final blow to the organization. The focus of the struggle has changed from the companies owned by the organization and its civilian-facade structures to discharging its cadres from the state, especially the Turkish Armed Forces (TAF). Preparations for the Supreme Military Council ${ }^{2}$ in 2016 began in January, and were conducted meticulously based on information from diverse intelligence sources and the participation of many public institutions.

The government's targeting of Gülenists nested in the TAF was a big threat for the organization, because those members formed the backbone of the organization's overall structure. All of its other structures were positioned around the organization's network in the TAF, and the elimination of this backbone could lead to the dissolution of the organization. The or- ganization's network within the TAF was secret; any threat to it constituted a red line for the organization. No intervention into this confidential zone was to be allowed, and overstepping this red line was not to be allowed by any means. The organization lacked any legitimate means to remove this threat; thus, the organization's nested TAF members became determined to use any means to eliminate the threat that targeted the organization's very existence. Therefore, the organization organized a coup d'état, as there was no other way out.

Meanwhile, within the international context, Turkey's diverging foreign policy preferences had led to discontent among the Western bloc regarding Turkey's foreign policy orientation. Considering that this could provide a convenient ground for acquiring international support, 
the Gülenists decided to abolish the democratically-elected government and to overthrow President Erdoğan.

\section{The State of the Turkish Judiciary during the Coup Attempt}

FETÖ had infiltrated not only in the TAF but also within Turkey's judicial institutions. In fact, its presence in the judiciary was so strong that it was surpassed only by that in the security bureaucracy. When the organization believed itself to have sufficient power, it did not hesitate to exploit all the institutions at its disposal to reach its political, economic and social objectives. Accordingly, the organization prioritized using the judiciary as a means to reach its ultimate goals. The operation planned and conducted through the judiciary against Hakan Fidan, the Chief of the National Intelligence Organization (MİT), on February 7, 2012 was unprecedented in terms of its method and possible outcomes. Similarly, one of the most striking examples of instrumentalizing the judiciary was the unauthorized investigations on the then Prime Minister Erdoğan, his family and certain government officials on December 17-25, 2013. The plan seemed pretty simple: in appearance, the investigations would be implemented by judges and prosecutors under the guise of high legitimacy, but in fact, the organization would reach its goals through its members nested in the judiciary.

The October 12, 2014 elections of the Supreme Council of Judges and

\section{When the organization} believed itself to have sufficient power, it did not hesitate to exploit all the institutions at its disposal to reach its political, economic and social objectives

Prosecutors (SCJP) set the most critical threshold in the struggle against the organization. If it were to win the SCJP elections, the organization would lead in the power struggle and, under judicial guise and with high legitimacy, it would eliminate the threats posed by the executive and judicial branches. At the same time, for the authorities fighting against the organization, losing the elections would eventually mean the failure of the struggle.

The power of the organization within the judiciary was no secret. However, there was no consensus on the number of Gülenist members in the judiciary. Estimates varied from 2,000 judges and prosecutors to $3,500-4,000$, out of a total of approximately 14.000 judges and prosecutors. Some did not hide their affiliation with the organization, but most chose to practice of taqiyyah, ${ }^{3}$ namely the concealing of their affiliation in order to blend in. For this reason, it was impossible to know the exact number of FETÖ members. Under these circumstances, in order to eliminate the risks regarding the 


\section{In the morning of July 16,} when it became apparent that the coup attempt had failed, the forensic investigations that had been launched in the early hours of the coup attempt gained momentum picture was grave. Almost half of the judicial members, which amounted to about 5,000 judges and prosecutors, were affiliated with FETÖ. The situation was not sustainable by any means.

Almost all the judges and prosecutors affiliated with FETÖ were still working during the coup attempt on July 15, 2016. A limited number of them, those who explicitly exploited their positions and illegally used the judicial institutions for the goals of FETÖ, had been suspended from duty, but none had been dismissed from their professions. In the early hours of the coup attempt, many of the affiliated judges and prosecutors mobilized, and some of them attempted to head for courthouses late at night. According to evidence obtained during the judicial inquiries later on, the FETÖ-member judges and prosecutors had been aware of the coup attempt in advance and appeared ready to do their share of duty if the coup attempt were to be successful. In the morning of July 16 , when the failure of the coup attempt became apparent, the Turkish judiciary had to contend with both the coup plotters and their colleagues who supported, or were ready to support, the coup.

FETÖ still had serious power in the judiciary. But the other members of the judiciary, constituting the small majority, were against the coup attempt, and opposed the organization behind the coup attempt and its goals. The non-affiliated majority of the judiciary was determined to protect the democratic state governed by the rule 
of law. In the early hours of the coup attempt, at a time when no one knew whether or not the coup attempt would be successful, and even when its success appeared highly probable, the Turkish judiciary launched an investigation into the FETÖ-member coup plotters and shared this decision with the public.

This attitude of the judiciary was a very brave and principled one, to which the Turkish judiciary was not accustomed, nor had history witnessed. If the coup attempt had been successful, those who displayed this attitude could have paid a high price with their lives. But this would have been of no significance, because there would no longer have been a democratic state governed by the rule of law if the coup attempt had succeeded and the terrorist organization dominated. It would not be possible to live in such a country, nor would it be possible to function as a judge or prosecutor.

\section{Difficulties in the Investigations, Destruction of Evidence}

In the morning of July 16 , when it became apparent that the coup attempt had failed, the forensic investigations that had been launched in the early hours of the coup attempt gained momentum. However, difficulties were experienced in obtaining evidence and taking the coup plotters into custody.

Most of the soldiers and upper civilian ranks of FETÖ who had taken part in the coup attempt had gathered at the Akınc1 Air Base, the command center of the putschists in Ankara. On the morning of July 16, the public prosecutor who went to the base to collect evidence was not allowed in. Only a military prosecutor from the General Staff was allowed in. This military prosecutor turned out to be a FETÖ member. Together with the military putschists at the Akınc1 Air Base, he proceeded to destroy evidence for hours. According to various witness statements, many forms of evidence, including digital evidence, cell phones, printed papers, video footage, and hard discs were burnt. Similar destruction took place in the military barracks where entry was not possible for some time. For instance, the hard discs containing security camera footage from the General Staff headquarters and other digital evidence were crushed under tanks.

\section{The Litigation Process: The Number and Nature of the Cases}

Despite all of the attempts of the putschists to destroy evidence, plenty of evidence was obtained which shed light on the coup attempt. Besides, the testimonies of the confessing soldiers were satisfactory enough to illuminate many dark spots. All of the collected evidence indicates that the coup attempt was plotted and carried out by FETÖ.

Inquiries concerning the coup attempt were conducted in many provinces all over Turkey, particularly in 
Defendants were tried in

fairness at independent and

impartial courts that had been established by law prior to the date of the crime and those who were accused by the public prosecutor of being members of the so-called "Peace at Home Council" were tried. This trial has been concluded with a verdict. The Akıncı Air Base Trial involves all of the defendants accused of committing crimes within the coup attempt at all air bases across Turkey and at the Air Force Command. No verdict has been reached yet in this trial, in which the civilian FETÖ imams, leaders of the organization taking orders from Gülen have been indicted. Adil Öksüz, imam of the FETÖ structure in the Turkish Armed Forces; Kemal Batmaz, imam of the Air Force; Nurettin Oruç, imam of the General Command of Gendarmerie; Hakan Çiçek, imam of the Naval Force Command; and Harun Biniş, a top civilian imam, all stand trial. All of these civilian imams were present at the Akınc1 Air Base on the night of the coup attempt. A preponderance of evidence indicates that they gave instructions and orders during the coup attempt in coordination with Fetullah Gülen, the FETÖ leader living in the U.S. As a result, Gülen has been identified as defendant number one in all of the coup-related cases across Turkey.

\section{FETÖ's Approach to the Cases: The Defense Strategy of the Defendants}

As a global organization, prior to the coup attempt, the Gülenist organization had been known as a civilian religious entity rejecting violence, and active in over 150 countries alongside Turkey. The July 15 coup attempt was 


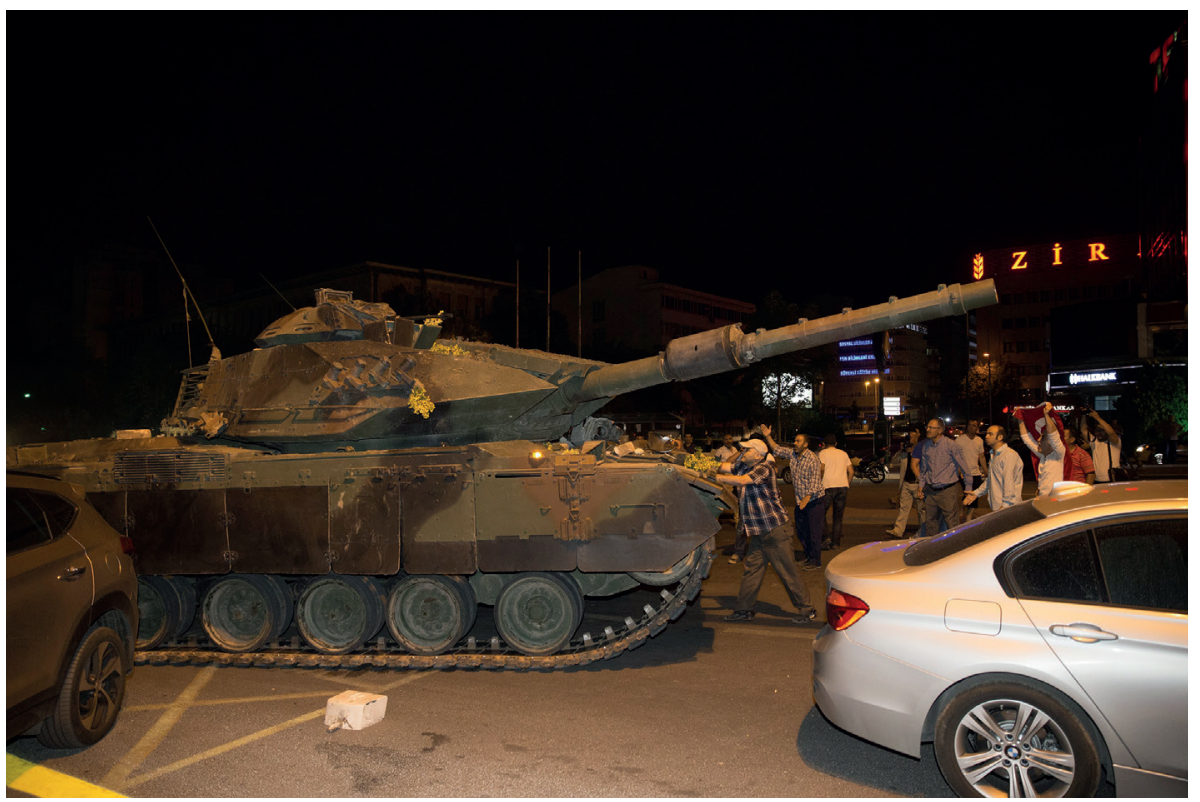

The citizens who opposed the FETÖ members' coup attempt gathered before the Turkish Armed Forces General Staff's compound and resisted against the coup plotters in Ankara on July 15, 2016.

a bloody and outrageous move, turning upside down the overall image of the organization across the world. As a result of the coup attempt, some states have designated FETÖ as a terrorist organization and banned its activities.

Since the July 15 coup attempt was carried out by FETÖ, the majority of the defendants were FETÖ members, or sympathized with the organization or were affiliated with it for different reasons. Many of the defendants were very well educated with the Turkish criminal jurisdiction practice. Both the high education level of the defendants and their training by FETÖ have resulted in their staging of unprecedented tactics and strategies during the criminal proceedings.

Most of the defendants have acted upon a common defense strategy.
This strategy was, without a doubt, determined and imposed on the defendants by the organization. The strategy can be explained as erasing the fact by fragmenting it into small pieces and creating a perception of reality by combining fragments of lies in a reasonable and consistent way. The reality to be erased was that the July 15 coup attempt was a coup by FETÖ and disastrous actions were committed as parts of it. The false perception of reality that needed to be created was the lie that the July 15 coup attempt was a controlled coup planned by President Erdoğan. In the context of this strategy, FETÖ determined which parts of the reality should be blacked out by defendants, and which lies should be told by whom in order to create a false perception of reality. These had been designated one by one and conveyed to the defendants. 
While the majority of the defendants followed the abovementioned strategy since the moment they were taken into custody, a small group of defendants, for various reasons, shared the facts as they were. The latter group submitted striking and detailed information in their initial testimonies concerning the link between the July 15 coup attempt and FETÖ. However, during the proceedings, most of this second group of defendants rejected their previous statements.

Shocked by the failure of the coup attempt, FETÖ could not manage to effectively contact its members for a short period of time. During this period, some military and civilian members, who had lost communication with the organization and experienced a serious trauma, and thus were feeling less attached to or even departing from the organization, told the truth in all of its nakedness. They made clear-cut and convincing statements, in particular about the organization's connection with the coup attempt.

However, FETÖ quickly recovered this brief initial shock. Its main priority was to prevent the coming to light of statements and evidence that would reveal the connection between FETÖ and the coup attempt, and to spoil the previously provided evidence and testimony. At this stage, the legal status of FETÖ members taking part in the coup attempt and the punishments they would face were of no concern. First, the organization would be dissociated from the coup attempt and then the state of the members of the organization would be dealt with. Because everything was for the organization, which they referred to as "Service" (Hizmet), everything, including life, could be sacrificed for the cause.

The organization was able to rebuild a sense of belonging by meeting all the needs of its members on trial, showing solidarity with them and especially looking after their families. After the organizational link was re-established, the instructions from the organization began to be fulfilled without any reservation as before. The main task that the organization imposed on the defendants in the context of the coup proceedings was primarily to strictly reject any organizational affiliations to clear the organization from the coup attempt, to question the realities of July 15, and to serve the perception that FETÖ wants to create about July 15.

Denial of the statements that revealed the connection between the coup attempt and FETÖ upon FETÖ's inculcations, had no legal consequences in many cases, because most of these statements had been given under the supervision of a lawyer before a prosecutor and the court. Some of the testimonies that had been given at police stations were also taken in the presence of lawyers. However, for FETÖ, it was not important that this strategy did not work in first-degree courts. FETÖ was acting according to a comprehensive strategy that would extend all the way to the European Court of Human Rights. Moreover, for FETÖ members, the 
perception of their organization by the public was as important as the court verdicts.

\section{Discussions on Fair Trial}

Defendants were tried in fairness at independent and impartial courts that had been established by law prior to the date of the crime. Suspects taken into custody due to the coup attempt were informed in a timely manner about the particulars of the charges. They were provided with opportunities to defend themselves in person and/or with the assistance of their lawyers. The statements they gave to the police, the prosecution, and the criminal courts, were provided under the supervision of a lawyer.

During the proceedings, the principle of "equality of arms" ${ }^{4}$ was respected. In this regard, the defendants were granted equal rights with the prosecution and the intervening parties (such as governmental institutions, political parties, bar associations, victims of the coup attempt, related civil society organizations) in terms of obtaining information and documents. No evidence was hidden from the defendants. In order to reach any evidence that they need at any time, all kinds of technical facilities were provided in the prison where the defendants were detained. Not only witnesses presented by the prosecution and the intervening party, but also those who were requested by the defendants were given the opportunity to be wit-

\section{The Turkish courts did not take shorts-cuts such as making a choice between applying the principles of fair trial and rushing to punish the offenders}

nesses. The defendants were able to freely interrogate the witnesses and plaintiffs. In fact, the courts generally tolerated the defendants' provocative questions.

The defendants' requests for expert examining were not categorically rejected; requests that could contribute to the merits of the case were accepted. The defense rights of the defendants were respected. Their defense was not interfered with. The courts usually tolerated the defendants' statements in the form of irrelevant organization propaganda, accusations of non-trial persons, some of which included humiliating allegations, implicitly threatening the court and thus abusing the right of defense. Even statements unrelated to the accusation, which lasted for hours or even days, were not interrupted. In this way, the defendants were allowed to complete their defense as they wished and planned. The defendants were given reasonable time to prepare for their defense. Those who could not prepare their defense in time for any reason were given additional time upon their request. 
Zekeriya Kuzu, who was involved in the assassination attempt of

President Erdoğan on the night of the July 15 coup attempt, was taken to trial under heavy security measures on July 13, 2017 in Muğla, Turkey. MUSTAFA ÇIFTÇi / AA Photo

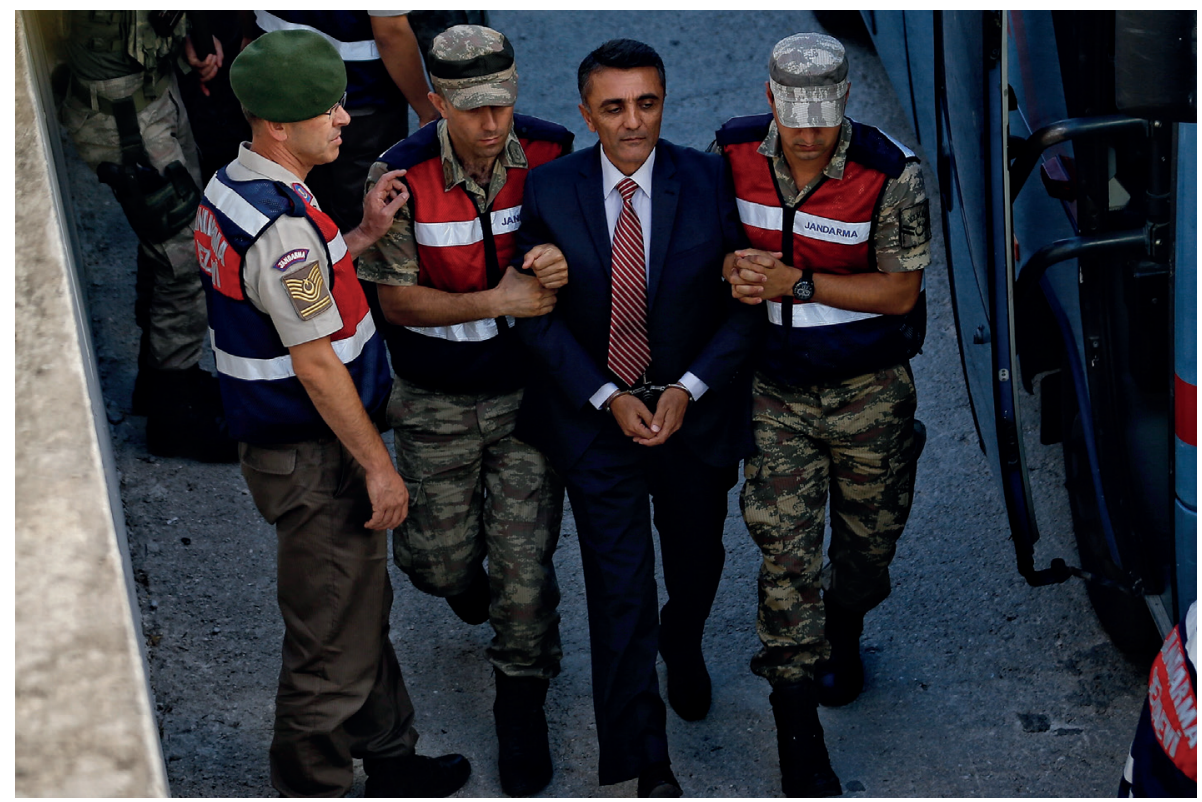

The defendants were permitted to participate in the proceedings effectively and to be present at the hearings. In addition to the first and the last defenses, the defendants were able to make statements about their detentions at all hearings, and comment on the evidence that entered the file. Illegally obtained evidence was not taken into consideration in the judgments. The proceedings were public, and the hearings were open to everyone. Other than the plaintiffs and the defendants' relatives, members of the press and citizens who were not a party to the case could attend the hearings. The verdicts were publicly declared.

Considering the number of defendants and the scope of the files, the proceedings were concluded in first-degree courts within a reasonable time. First-degree appeals and appeal stages were also concluded in a reasonable time. In summary, despite all difficulties, the coup cases were conducted in accordance with the fair trial principle. In terms of the fair trial principle, the standards set forth in the trial proceedings in these court cases exceeded Turkey's normative trial standards.

In FETÖ's publications and by those who are under the influence of these publications, it is widely claimed that the defendants being tried for the coup attempt were treated with a wholesale approach and that everyone was declared guilty in advance. This claim by FETÖ, like its other claims, does not reflect the truth. Many of the coup cases were resolved in local courts. When we examine the content of the court decisions, it will be seen that we are faced with a completely different picture. According 
to the data shared by the Ministry of Justice, the verdicts reached for 268 coup cases and judgments are as follows: aggravated life imprisonment for 1,216 defendants, life imprisonment for 1,097 defendants, imprisonments ranging from 1 year 2 months to 20 years for 1,491 defendants, acquittal for 2,621 defendants, and no need to inflict punishment for 525 defendants.

As for the ranks of the soldiers that were given judgment, the majority of the top-ranking officers received aggravated life imprisonment or life imprisonment. Most of the lower-ranking officers, non-commissioned officers, and other non-ranking soldiers were sentenced to varying imprisonment terms. The majority of those who were acquitted predominantly consisted of enlisted men, privates, specialist sergeants, and other lower-ranking soldiers. These data show that the soldiers who took part in the coup attempt were classified according to their level of contribution to the coup attempt. Those who more significantly contributed to the coup attempt, especially those in executive positions, were penalized with more severe punishments. Those who had lesser involvement were punished with lighter penalties, while those who only unknowingly participated in the incidents were not punished at all.

As can be understood from the verdicts, the decisions were not reached via a wholesale approach, and the legal status of each defendant was eval-
The coup cases were handled through a process of effective investigation and punishment of those taking part in the coup attempt. The cases represent a test for the judiciary, particularly in terms of the rule of law and the fair trial principle

uated individually and according to the scope of the file.

\section{Concluding Remarks}

At the time of the writing of this paper, 268 of the 289 coup cases were concluded by the local courts, and 21 of them were ongoing. Four coup cases were finalized without appeal. 22 out of 90 coup cases were reversed after the first-degree appeal and sent back to the first-degree court; the first-degree appellate reviews of the remaining continue. Out of 162 cases on appeal at the Court of Cassation, 17 of them were affirmed and finalized, 12 were reversed. Appellate reviews on the remaining 133 files continue at the Court of Cassation.

It is a fact that in the Turkish criminal judiciary practice, multi-accused and comprehensive cases can last for years, and consequently the cases are dropped due to the statute of limitations. However, in order 
to prevent this from occurring in the coup cases, necessary measures such as the appointment of substitute panels to the courts were taken in a timely manner. In addition to these measures, uninterrupted trial sessions in the courts and the superhuman efforts of the judges greatly contributed to the conclusion of the coup cases within a reasonable time. The courts did not give way to the attempts of the accused to extend the cases through irregular and unjust demands.

The Turkish courts did not take shorts-cuts such as making a choice between applying the principles of fair trial and rushing to punish the offenders. Despite the widespread anger in the community against the perpetrators and the social demand for serial punishment of those found guilty, the principles of fair trial have not been compromised. On the contrary, utmost efforts have been made to ensure the conduct and conclusion of the proceedings in a fair manner.

In the early days of the trial process, the defendants' attitude of no regret and their relaxed behavior during the hearings caused reactions in the wider society. These reactions turned into a dominant demand for making the defendants wear uniform outfits. However, considering the drawbacks it could create in terms of maintaining fair trial principles, the govern- ment resisted this social pressure and did not implement a dress code for the defendants.

The coup cases were handled through a process of effective investigation and punishment of those taking part in the coup attempt. The cases represent a test for the judiciary, particularly in terms of the rule of law and the fair trial principle. It is possible to say that the judiciary has passed this test successfully and is gaining strength.

\section{Endnotes}

1. The terms Gülenist organization and FETÖ will be used interchangeably throughout this article.

2. The Supreme Military Council (Yüksek Askeri Şura, YAŞ) is a body in the Turkish Armed Forces. It is headed by the President and consists of related ministers and commanders of armies and other admirals/generals. It convenes annually during the first week of August to determine the military agenda and to make appointments.

3. Taqiyyah is a key tactical concept within the ideology of the founder of FETÖ, Fetullah Gülen, and the organization's structure and members. In a broad sense, taqiyyah can be defined as concealment and dissimulation. According to this concept, members of the cult are permitted to violate religious creeds and codes in order to blend in with the non-religious majority in certain organizations that they are asked to infiltrate.

4. The principle of "equality of arms" is a jurisprudential concept created by the European Court of Human Rights and is a part of the right to fair trial written in the Convention for the Protection of Human Rights and Fundamental Freedoms, better known as the European Convention on Human Rights. Equality of arms requires that there be a fair balance between the opportunities afforded the parties involved in a trial. 